\title{
The Effectiveness of Contextual Research-Based Teaching Materials on Students' Learning Independence and Concept Mastery
}

\author{
Linda Lidiawati ${ }^{*}$, Leny Heliawati ${ }^{2}$ Indarini Dwi Pursitasari ${ }^{3}$ \\ 1,2,3 Program Studi Pendidikan IPA Sekolah Pascasarjana Universitas Pakuan Bogor, Bogor, Indonesia \\ *e-mail: leny heliawati@unpak.ac.id
}

\begin{abstract}
Innovation in teaching materials used in online learning is very urgent based on students' needs. This study aims to measure the effectiveness of contextual research-based teaching materials to improve students' learning independence and concept mastery of acid-base solution properties. The research method is Research and Development, referring to Borg and Gall. The research subjects were 60 students and 7 science teachers who have used teaching materials based on contextual research findings. The data collection technique in this study is a test that aims to determine the concept mastery and a questionnaire to measure students' learning independence. Based on the results of the study, it is known that the average percentage of student learning independence is $78 \%$ (Good category). Besides, an average value of 73.83 is obtained with an N-Gain of $64 \%$ (Medium category). The use of contextual research-based teaching materials can increase learning independence in terms of information search and concept mastery of acid-base solution properties.
\end{abstract}

Keywords: Android-Based Teaching Materials; Learning Independence

\section{Introduction}

In early 2020 the World Health Organization announced the COVID-19 pandemic, which started in Wuhan, China. This ultimately has an impact on all aspects of human life, including educational aspects. Learning, which is always done face-to-face, suddenly has to be stopped and has to switch online (Yates et al., 2020; Fung \& Lam, 2020; Starkey et al., 2020). This is, of course, for the safety and security of students, parents, and teachers from the possibility of being exposed to this deadly virus. This learning change creates various problems, both the emergence of difficulties in understanding abstract concepts and low student learning independence. The difficulties in understanding abstract concepts can cause many mis-conception about science that will influence the quality of the students' life. In the other hand, the learning independence will affect the achievement of students' online learning in concept mastery.

The use of online learning media certainly requires the right technology by utilizing internet facilities (Broadbent \& Fuller, 2018; Martin \& Betrus, 2019). Android-based smartphones can be used as an alternative that can be selected as online learning media. Online learning is inseparable from the use of Android-based smartphones and social media, which are very attached to every human activity (Martin \& Betrus, 2019; Bahri et al., 2020). Online learning allows students, including shy students, to be more comfortable learning according to time and place, with easy access to media such as websites, virtual classes, collaboration through social media via their mobile devices (Khamparia \& Pandey, 2019; Yates et al., 2020). This can be facilitated by selecting the correct application, such as Office 365 , to provide interactive online learning. Microsoft Sway, which provides a more dynamic and interactive display than Microsoft PowerPoint, can be used as an alternative learning media (Wihartanti \& Wibawa, 2017). This technology can facilitate students in obtaining teaching materials based on contextual research more enjoyably, according to students' characteristics.

\footnotetext{
${ }^{*}$ Corresponding author.
}

Received May 03, 2021; Accepted July 18 2021; Available online December 25, 2021

This is an open access article under the CC BY-SA license. Copyright $(2021$ by Author. Published by Universitas Pendidikan Ganesha 
The characteristics of junior high school students include adolescents who have a very active character in using digital technology (Sulistiyarini \& Sabirin, 2020). The problem that arises for students is the low ability to check the validity, credibility, and quality of various information sources available on the internet (Lai et al., 2018). Introduction to information sourced from contextual research is essential to be given to junior high school students to develop skills in decision making, especially in solving problems that arise in the daily lives of individuals. The concept of the properties of acid-base solutions is abstract, so it requires a special presentation. One of them is providing teaching materials based on contextual research related to various aspects such as types of food and beverages, health, and the environment (Paristiowati et al., 2019). This is the urgency of developing student learning independence in terms of information retrieval through the provision of contextual researchbased teaching materials.

Previous studies on learning acid-base solutions were carried out using the scientific literacy approach (El Islami et al., 2016), learning cycle 5E (Cetin \& Geban, 2017), STEAM (Apriliana et al., 2018), discovery learning (Setiadi \& Zainul, 2019) and problem-solving (Rasmawan, 2020). As for making teaching materials on the concept of existing acid-base properties, using Microsoft PowerPoint (Kazanidis \& Valsamidis, 2019), virtual lab (Muchson et al., 2018), e-module (Setiadi \& Zainul, 2019), Microsoft Sway (Harefa et al., 2019), to the android application (Eliyawati et al., 2020). Research on independent learning shows students who have clear learning goals, self-confidence, learning without helps of others, and a positive correlation with academic success in distance learning (Pardo et al., 2017; Rodiah et al., 2020). Students who have independence in actively seeking learning resources also have higher learning achievement (So et al., 2019). One of the limitations in previous studies is that it focuses too much on the metacognitive aspects of learning independence (Hartley et al., 2020) but has not yet explored the skills aspect in seeking information on learning resources. Based on the problems faced during this pandemic, it is crucial to carry out a learning innovation by the teacher to produce online learning effectively and efficiently.

The research objective is to measure student learning independence using contextual research-based teaching materials and concept mastery of acid-base solution properties. Independence learning in this study means students seek and use learning resources essential to do during online learning. For this reason, this study investigates the effectiveness of the use of contextual research-based teaching materials on student learning independence, especially in the aspect of searching for information sources via the internet and the extent to which students master the concept of acid-base solution properties. This study's results are online learning innovations for teachers to develop teaching materials based on contextual research using Microsoft Sway software that can be accessed easily via any device smartphone Android.

\section{Method}

This study was a Research and Development study (RnD) (Gall and Borg (2003). The research stages include three stages, which consist of 1) Preliminary study by conducting a pretest on the properties of acid-base solutions; 2) Development of contextual-based teaching materials; 3) Validation of teaching materials using Android. This research was conducted at SMPN in Bogor City towards 60 students taken through the purposive sampling technique. The research location selection is based on the school's location, which is in the middle of the city and very close to shopping centers such as malls and traditional markets. The research was conducted during the online learning period, which was the impact of the COVID-19 pandemic. This affects the characteristics of junior high school students who are accustomed to buying various snacks such as snacks and soft drinks. Students' parents who are busy working often provide soft drinks as a refreshment without paying attention to longterm health effects. The variables determined in this study include the independent variables, namely the contextual-based acid-based solution teaching material, while the dependent variable is the level of independent learning and student learning outcomes. This R\&D stage is limited to the media development stage with limited trials, using a one-group pretest- 


\section{posttest design.}

In the first stage, a preliminary study was carried out. It consists of conducting a field survey, studying literature, and preparing for making teaching materials based on contextual research. The field survey was carried out following the health protocol during a pandemic so that it was carried out online through the Google Form application. This application link is given to 40 science teachers at the destination school via WhatsApp to be forwarded to 200 students via the WhatsApp Group for Science subjects. The survey's target was junior high school class VII first semester students who had not received material on the properties of acid-base solutions. Things that were surveyed were the extent to which the participant's level of independence in implementing online learning, how participants obtained information to fulfill assignments given by the teacher, and how participants understood the concept of science with online learning methods. In the field survey, a pretest was also carried out in multiple choices regarding acid-base solutions' properties as many as ten questions based on contextual research. Further, data processing is carried out through the use of the IBM SPSS version 26.0 application.

The second stage begins with developing contextual research-based teaching materials reviewed by material experts, followed by a review by seven science teachers. The posttest will be held after students are given teaching materials based on contextual research. The posttest consists of ten multiple-choice questions regarding the material of acid-based solution properties based on contextual research, both related to health and the environment. Contextual-based questions include the effect of consuming soft drinks, the use of baking soda as first aid for poisonous bee stings, and the effects of air pollution on the intensity of acid rain. The questionnaire test contains 20 questions about student learning independence and 5 points of assessment on contextual research-based teaching materials. A Likert scale with a score of 1-4 is used in the questionnaire assessment, while the assessment of the use of teaching materials uses the numbers 0 (none) and 1 (occur). The pretest, posttest, and questionnaire questions have passed the validity test, and all the questions gave have been valid and reliable.

The results of the pretest and posttest are then calculated for normality first to find out that the data is normally distributed through the Kolmogorov Smirnov test with SPSS version 26.0. The data will be considered normally distributed at a value of $\alpha=0.05$ if it meets the requirements of the Asymp. Sig value ( 2 tailed) $>0.05$. If the value is normally distributed, then be followed by paired sample t-test. Conversely, if the value is not normally distributed, the Wilcoxon non-parametric test type must be applied (George \& Mallery, 2018). A sample t-test is conducted to determine the significant difference between the pretest and posttest results. This test is used for paired data and processed using SPSS version 26. Decisionmaking is based on obtaining the Sig. Value (2-tailed) $p<0.05$, which indicates a significant difference between the pretest and posttest results. If the Sig. Value (2-tailed) is $p>0.05$, so there is no significant difference in the study. After the data is declared normally distributed, the N-Gain test.The effectiveness of using teaching materials based on contextual research can be seen from the increase between the pretest and posttest scores through the N-Gain value. Teaching materials based on contextual research are declared effective if the N-Gain value is $\geq 0.3$ or falls into the medium or high category. 


\section{Result and Discussion}

\section{Results}

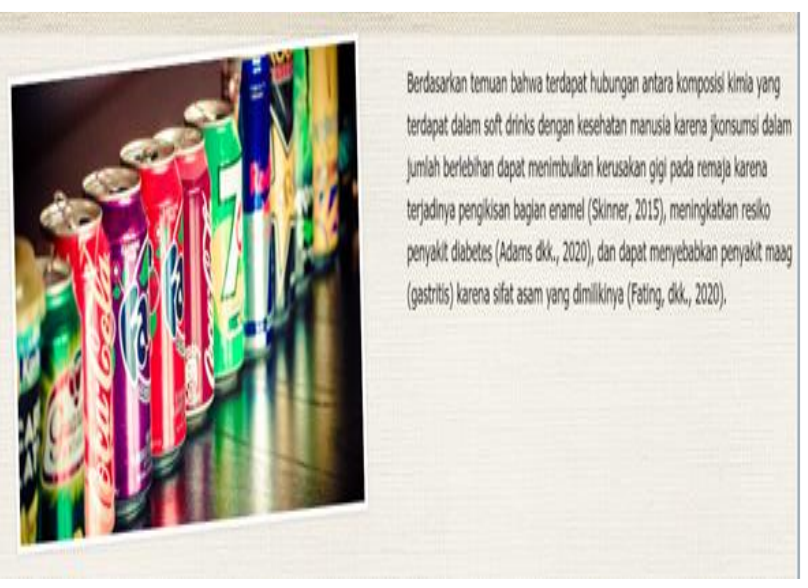

Figure 1. Contextual Research-Based Materials

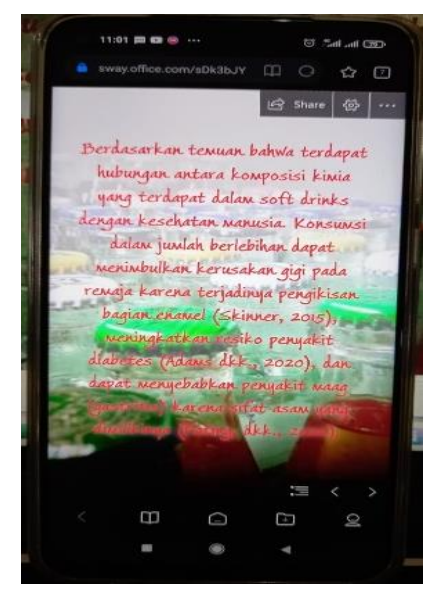

Figure 2. Android Display

The development of contextual research-based teaching materials on Acid-Base Solution material has gone through various validation processes by both experts and teachers. This material was created via Microsoft Sway, and links are provided to validators and students via Google Forms. Contextual research-based material from various national and international journals included in the acid-based solution teaching material (Figure 1). The display on an Android device can be seen as shown in Figure 2. Specifications for contextual research-based teaching materials using Android compared to other printed teaching materials are in Table 1. Microsoft Sway is very easy to use and has an attractive visual appearance to support interactive online learning.

Table 1. Comparison of Contextual Research-Based Teaching Material Specifications

\begin{tabular}{|c|c|c|}
\hline Aspect & $\begin{array}{c}\text { Contextual Research-Based } \\
\text { Teaching Material }\end{array}$ & Printed Teaching Material \\
\hline Material & $\begin{array}{l}\text { Derived from contextual research } \\
\text { findings from national and } \\
\text { international journals }\end{array}$ & $\begin{array}{l}\text { Materials are not contextual and } \\
\text { less relevant }\end{array}$ \\
\hline Display & Interesting and interactive & less attractive and not interactive \\
\hline $\begin{array}{l}\text { Learning } \\
\text { orientation }\end{array}$ & $\begin{array}{l}\text { Encouraging students' } \\
\text { independence in the search for } \\
\text { information sources }\end{array}$ & Still relying on teacher guidance \\
\hline Flexibility & Very flexible, easy to carry & Less flexible, heavy to carry \\
\hline Audio Visual & $\begin{array}{l}\text { More attractive because it can be } \\
\text { equipped with audio and video in } \\
\text { one presentation }\end{array}$ & $\begin{array}{l}\text { Less attractive, can only be } \\
\text { equipped with illustration images }\end{array}$ \\
\hline Evaluation & $\begin{array}{l}\text { More efficient for teachers } \\
\text { because it can know the results of } \\
\text { student evaluations directly }\end{array}$ & $\begin{array}{l}\text { The teacher cannot know the } \\
\text { results of student work directly }\end{array}$ \\
\hline $\begin{array}{l}\text { The risk of } \\
\text { COVID-19 } \\
\text { transmission }\end{array}$ & $\begin{array}{l}\text { very low because it is easy to } \\
\text { share with students via a link } \\
\text { without having to face to face }\end{array}$ & $\begin{array}{l}\text { High risk because it needs to do } \\
\text { a face-to-face meeting or } \\
\text { expedition delivery }\end{array}$ \\
\hline
\end{tabular}

As for the final evaluation, it can be made through the Google Form application, or Microsoft Form, where the link is embedded into the teaching material, so that students can immediately know the results after completing all the questions. Validation carried out by 
experts (lecturers) and teachers of Android-based teaching materials includes three aspects, namely language and legibility, material, and presentation aspects. The results can be seen in Figure 3.

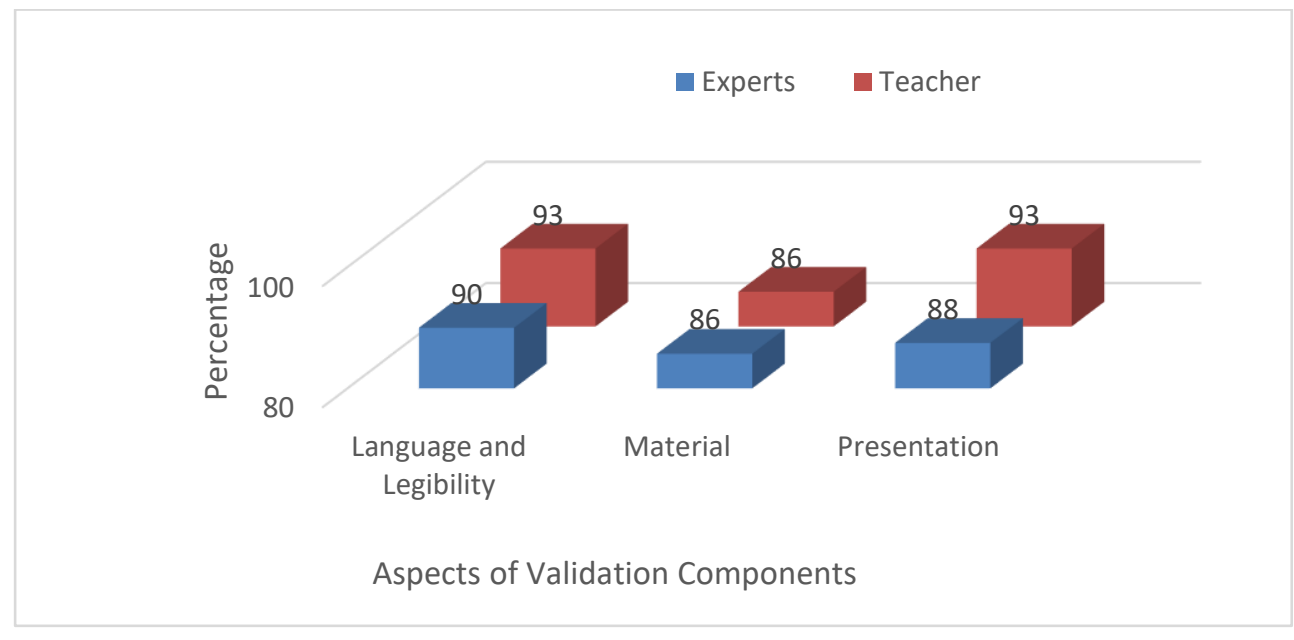

Figure 3. Validation Results of Android-Based Teaching Materials by Experts and Teachers

Figure 3 shows the validity of teaching materials by two experts (lecturers), achieving the highest score of $93 \%$ in the aspects of language and legibility, $88 \%$ in the presentation aspect, and $86 \%$ in the material aspect. The validation carried out by seven teachers showed maximum results in language and readability, and presentation, namely $93 \%$, but in the material aspect, the score was $86 \%$. This is possible because the display of contextual research-based teaching materials is still something new for junior high school teachers so that further exploration is needed regarding the results of scientific research following junior high school science material.

The use of contextual research-based teaching materials that use Android as an online learning medium has benefited both teachers and students. This is known by analyzing teacher and students' responses to the acid-base solution teaching materials in Figure 4.

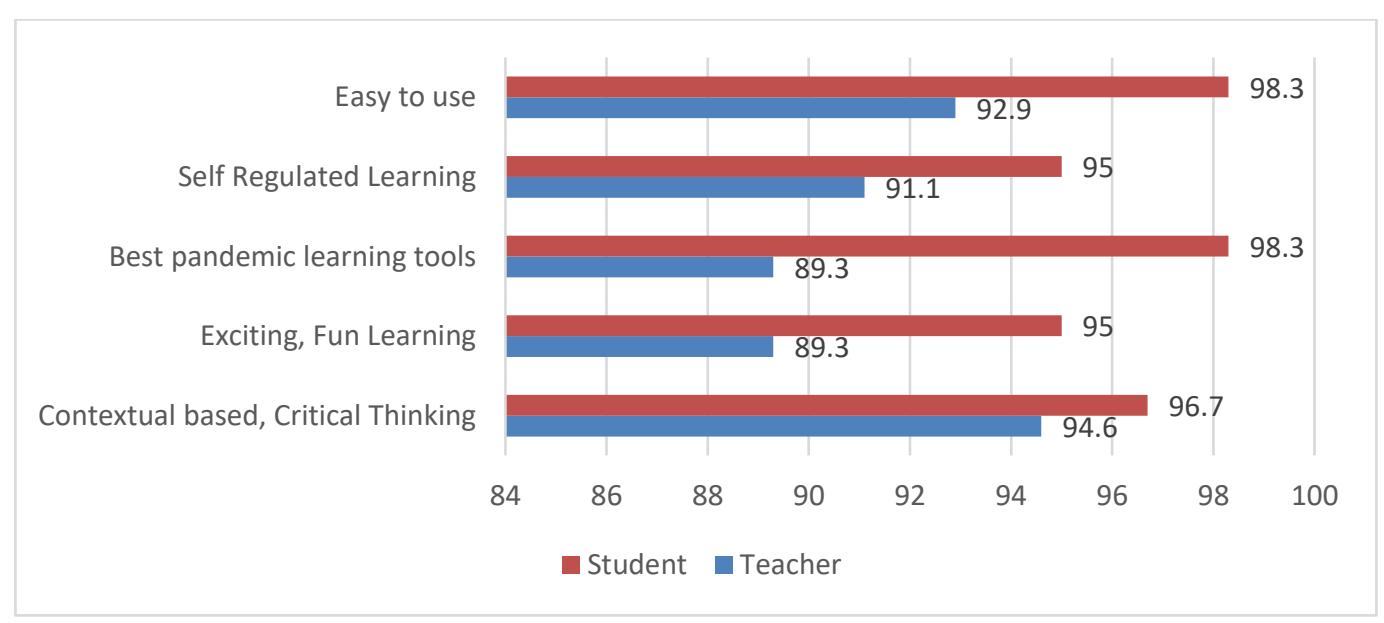

Figure 4. Students and Teachers' Responses to the Use of Contextual Research-Based Teaching Materials

The percentage of student acceptance of the use of contextual-based teaching materials shows that the highest percentage of $98.3 \%$ is in the aspect of ease of use, and $98.3 \%$ of students agree that contextual research-based teaching materials using Android are one of the best alternatives to learning during a pandemic. Meanwhile, 92.9\% of teachers 
consider this teaching material easy to use, and $89.3 \%$ have used teaching materials using Android to facilitate students' learning online apart from WhatsApp.

The use of contextual research-based teaching materials using Android is considered by $96.7 \%$ of students and $94.6 \%$ of teachers that it can improve thinking skills through provision material in the form of articles relevant to everyday life, followed by giving ten multiple-choice questions with High-Order Thinking Skill oriented. Besides, 95\% of students consider the teaching material using Microsoft Sway to be engaging with an interactive visual display so that online learning during the pandemic period becomes more accessible and more fun. Teaching materials based on contextual research can also develop independent learning, especially in terms of information retrieval, as recognized by $95 \%$ of students and $91.1 \%$ of teachers

Based on research on 25 male respondents and 35 female respondents, it was found that the posttest scores showed an increase in the average score compared to the pretest scores (Figure 5).

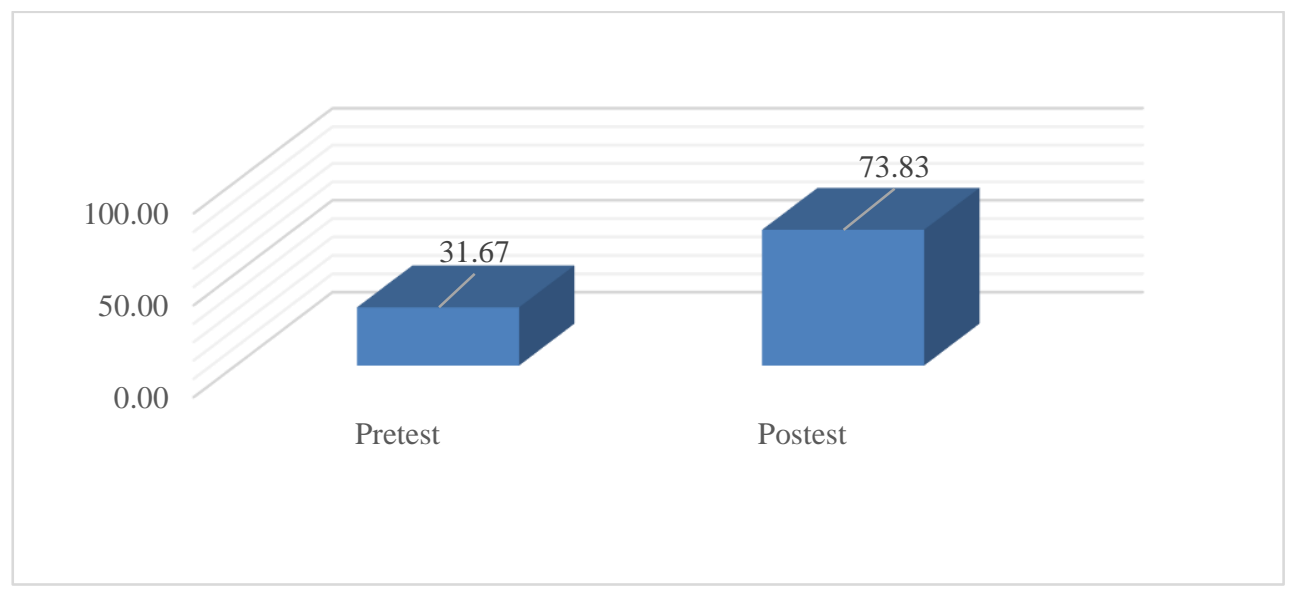

Figure 5. Comparison of the Average Scores Between the Pretest and Posttest

The data analysis process was then followed by the Kolmogorov Smirnov normality test using SPSS version 26.0 and the Asymp value obtained Sig. (2-tailed) of $0.000<0.05$, so it can be concluded that the data are not normally distributed. Furthermore, the Wilcoxon test was carried out and resulted in a value of $0.000<0.05$, which means that there was a significant difference between the pretest and posttest assessments. It means that this teaching material is very significant in improving students' concept mastery.

Furthermore, an analysis of the research data has been carried out through calculating the average score, which is then calculated the percentage classically, then from the calculation, it turns out that the average value of $\mathrm{N}$ Gain is 0.66 (Table 4). The acquisition of N Gain belongs to the medium category which refers to Hake (1999).

Table 4. Comparison of Teaching Material Specifications Based on Contextual Research

\begin{tabular}{lcc}
\hline \multicolumn{1}{c}{ Data } & Pre-test & Post-test \\
\hline Number of respondents & 60 & 60 \\
Minimum score & 0 & 50 \\
Maximum score & 70 & 100 \\
Average score & 31,67 & 73,83 \\
N-Gain percentage & $64 \%$ & Medium category \\
\hline
\end{tabular}

\section{Discussion}

The development of self-regulated learning can be identified through various indicators, and this study is limited to five indicators adapted from Schunk (2011), namely intrinsic motivation, information seeking, self-efficacy, self-evaluation, and self-regulation. 
The indicator of the ability to search for information using an Android device reaches the highest percentage, namely $79.6 \%$ in Information Seeking. The results of the review of contextual research findings are then followed up through self-evaluation activities. The ability of students to do self-evaluation is the second-highest score with a percentage of $79 \%$. Self-efficacy of students reached a percentage of $77.8 \%$, which indicates the fact that students are more confident in completing assignments without the help of others through using contextual research-based teaching materials. The respondents' learning independence (self-regulation) is in a good category with a value of $77.7 \%$, which means that students already have good learning independence by using teaching materials based on contextual research. Students' motivation to learn is in a good category $(76.9 \%)$, with the condition that students are quite enthusiastic about learning even though during the pandemic.

There are facts in the field that some teachers are still dominant in the use of WhatsApp social media as a learning tool during the pandemic. The ease of use of androidbased applications has provided benefits for teachers to provide material and questions that challenge students in solving problems (Liliarti \& Kuswanto, 2018; Giyanto et al., 2020). Contextual research-based questions can also be presented in a more attractive, interactive, and more accessible manner through using Microsoft Sway. The existence of contextual research-based articles with video views can stimulate students to be skilled in higher-order thinking (Danjou, 2020). Independent learning in finding various sources of information will also encourage students to undergo learning activities with their awareness so that it has a positive impact on learning outcomes. Online learning using contextual research-based teaching materials from various national and international journals can increase concept mastery of acid-based solution properties.

Teaching materials based on contextual research on the concept of the acid-base solution properties are provided through the provision of articles on the negative effects of consuming soft drinks (Skinner et al., 2015; Adams et al., 2020), the use of baking soda as one of the first aid when experiencing bee stings (Quade et al., 2021), as well as the effect of acid rain on organism life (Zhang et al., 2020) and resistance of building materials (Smolakova \& Estokova, 2020). The use of various references from Google Scholar will open students' insights and stimulate curiosity about various scientific research according to their learning needs (Rafika et al., 2017). This will develop students' learning independence in obtaining information through various relevant sources. This research also provides stimulus through videos, articles, and image presentations that can encourage thinking skills and student learning independence (Martin \& Betrus, 2019; Siahaan et al., 2020). The addition of a YouTube video embedded in teaching materials based on contextual research on forming acid rain can raise awareness about the importance of reducing carbon emissions, thereby having a positive impact on the environment

The indicator of the ability to search for information using an Android device reaches the highest percentage, namely Information Seeking, which indicates that online learning in the pandemic era is the easiest to find information through an android device (Bahri et al., 2020). Self-Evaluation which indicates the fact that with contextual research-based teaching materials, students can more easily do self-evaluation and get feedback on scores quickly. This will also accelerate the improvement process as a result of the independent evaluation process. Giving questions via Google Form embedded in Microsoft Sway is proven to facilitate the assessment of cognitive and affective aspects. The use of Android makes students more challenged in solving evaluation questions, according to their respective learning speeds (Habibi et al., 2018). The series of assignments given by the teacher, such as Student Activity Sheets, must be adjusted to the abilities of students both independently and in groups (Yessi et al., 2019; Pratama, et al., 2019). Students' success in solving these questions will foster self-confidence because they have completed the whole learning well.

Self-efficacy indicator is influenced by the preparation of teaching materials that are tailored to students' abilities and characteristics. The teacher must anticipate the pandemic situation that does not allow students to work in groups by providing assignments that can be completed independently. When students can complete well, their self-efficacy will grow to 
face other tasks to form self-regulation in learning. Students believe that an Android-based smartphone is a beneficial tool for individual success (Hendikawati et al., 2019). The making of Android-based teaching materials by teachers has proven to support the effectiveness of online learning (Hartley et al., 2020). This is, of course, a challenge for teachers to continue to develop teaching materials based on contextual research that can motivate students to continue learning independently during the pandemic.

The use of contextual research-based media using Android turned out to be more attractive to students' interest and attention to abstract material so that it has a positive impact on the mastery of science concepts (Bahri et al., 2020). Choosing the suitable learning method and strategy must also be considered because it will affect the students' concept mastery (Firmayanto, 2020). In efforts to encourage learning motivation, teachers must provide clear instructional goals so that students can determine learning strategies to achieve goals (Bovermann \& Bastiaens, 2020). Students who feel happy learning using contextual-based teaching materials will be more motivated to learn new things and are challenged to complete all given tasks. Students generally use search engines like Google, as described in previous studies (Özdener, 2018; Hendikawati et al., 2019). Teachers have a significant role in guiding students to independently evaluate the reliability of authors, sources of information, and scientific evidence. This scientific source of information can be obtained by providing teaching materials based on contextual research where students are introduced to digging various scientific facts.

\section{Conclusions and Suggestions}

Students with good learning independence can apply learning strategies, selfefficacy, learning motivation, evaluate their abilities, and search for information independently. The use of contextual research-based teaching materials using Microsoft Sway software which can be accessed via Android devices, is proven, from this research, to effectively improve the concept mastery of acid-base solution properties and student learning independence, especially in searching for information sources during this pandemic. As suggestion, teacher innovations in making contextual research-based teaching materials presented with an Android, still need more explored using any other digital software to maintain this effective student's learning activities.

\section{References}

Adams, S. O., Akano, R. O., \& Rauf, R. I. (2020). An Evaluation of the Chemical Composition of Soft Drinks in Nigeria: A Principal Component Analysis Approach. Advances in Modelling and Analysis A, 57(1-4), 14-21. https://doi.org/10.18280/ama_a.571-403.

Apriliana, M. R., Ridwan, A., Hadinugrahaningsih, T., \& Rahmawati, Y. (2018). Pengembangan Soft Skills Peserta Didik melalui Integrasi Pendekatan Science, Technology, Engineering, Arts, and Mathematics (STEAM) dalam Pembelajaran Asam Basa. JRPK: Jurnal Riset Pendidikan Kimia. https://doi.org/10.21009/jrpk.082.05.

Bahri, A., Ramly, Z. A., Nur, M. S., \& Pagarra, H. (2020). Android-Based Mobile Learning Supported the Independent Learning of Senior High School Students in Covid-19 Pandemic. Proceeding of The International Conference on Science and Advanced Technology (ICSAT), 22-32. https://ojs.unm.ac.id/icsat/article/view/17567.

Bovermann, K., \& Bastiaens, T. J. (2020). Towards a Motivational Design? Connecting Gamification User Types and Online Learning Activities. Research and Practice in Technology Enhanced Learning, 15(1). https://doi.org/10.1186/s41039-019-0121-4.

Broadbent, J., \& Fuller-Tyszkiewicz, M. (2018). Profiles in Self-Regulated Learning and Their Correlates for Online and Blended Learning Students. Educational Technology Research and Development, 66(6), 1435-1455. https://doi.org/10.1007/s11423-0189595-9.

Cetin-Dindar, A., \& Geban, O. (2017). Conceptual Understanding of Acids and Bases 
Concepts and Motivation to Learn Chemistry. Journal of Educational Research, 110(1), 85-97. https://doi.org/10.1080/00220671.2015.1039422.

Cohen, L., Manion, L., \& Morrison, K. (2000). Research Methods in Education. In Routledge (5th ed.). https://doi.org/10.1134/S0021364007220055.

Danjou, P. E. (2020). Distance Teaching of Organic Chemistry Tutorials during the COVID19 Pandemic: Focus on the Use of Videos and Social Media. Journal of Chemical Education, 97(9), 3168-3171. https://doi.org/10.1021/acs.jchemed.0c00485.

El Islami, R. A. Z., Nahadi, N., \& Permanasari, A. (2016). Membangun Literasi Sains Siswa Pada Konsep Asam Basa Melalui Pembelajaran Inkuiri Terbimbing. Jurnal Penelitian Dan Pembelajaran IPA, 2(2), 110. https://doi.org/10.30870/jppi.v2i2.662.

Eliyawati, E., Agustin, R. R., Sya'bandari, Y., \& Putri, R. A. H. (2020). Smartchem: An Android Application for Learning Multiple Representations of Acid-Base Chemistry. Journal of Science Learning, 3(3), 196-204. https://doi.org/10.17509/jsl.v3i3.23280.

Fating, M. S., Pashu, M., \& Bhandar, K. (2020). Assess the Knowledge Regarding Risk Factors of Gastritis Among Second Year Engineering Students. International Journal of Modern Agriculture, 9(3), 2305-7246. Retrieved from http://modernjournals.com/index.php/ijma/article/view/123.

Firmayanto, R., Heliawati, L., \& Rubini, B. (2020). Learning Chemistry in English: The Relationship between Language Skills and Learning Outcomes. Tadris: Jurnal Keguruan Dan Ilmu Tarbiyah, 5(2), 253-264. https://doi.org/10.24042/tadris.v5i2.6455.

Fung, F. M., \& Lam, Y. (2020). How COVID-19 Disrupted Our "Flipped" Freshman Organic Chemistry Course: Insights Gained from Singapore. Journal of Chemical Education. https://doi.org/10.1021/acs.jchemed.0c00590.

Gall, M. D., Gall, J. P., \& Borg, W. R. (2003). Educational Research: An Introduction. In Pearson Education (7th ed.). https://doi.org/10.2307/3121583.

George, D., \& Mallery, P. (2018). IBM SPSS Statistics 25 Step by Step. In IBM SPSS Statistics 25 Step by Step. https://doi.org/10.4324/9781351033909.

Giyanto, G., Heliawaty, L., \& Rubini, B. (2020). The Effectiveness of Online Learning by EdPuzzle in Polymer Materials on Students' Problem-Solving Skills. IOP Conference Series: Materials Science and Engineering, 959(1). https://doi.org/10.1088/1757899X/959/1/012006.

Habibi, A., Mukminin, A., Riyanto, Y., Prasojo, L. D., Sulistiyo, U., Sofwan, M., \& Saudagar, F. (2018). Building an Online Community: Student Teachers' Perceptions on the Advantages of Using Social Networking Services in a Teacher Education Program. Turkish Online Journal of Distance Education, 19(1), 46-61. https://doi.org/10.17718/tojde.382663.

Hake, R. R. (1999). Analyzing Change/ Gain Scores. Unpublised (Online).

Harefa, N., Fransisca Dewi Silalahi, N., Sormin, E., Sanga Lamsari Purba, L., \& Sumiyati, S. (2019). The Difference of Students' Learning Outcomes with Project Based Learning using Handout and Sway Microsoft 365. Jurnal Pendidikan Kimia, 11(2), 24-30. https://doi.org/10.24114/jpkim.v11i2.14459.

Hartley, K., Bendixen, L. D., Olafson, L., Gianoutsos, D., \& Shreve, E. (2020). Development of the Smartphone and Learning Inventory: Measuring Self-Regulated Use. Education and Information Technologies. https://doi.org/10.1007/s10639-020-10179-3.

Hasanah, I., Hasani, A., Fatah, A., Sari, I. J., \& Romdani, A. (2018). The Influence of Learning by Smartphone to the Conceptual Science Knowledge and the Independence of Student s ' Learning at Junior High School. Jurnal Penelitian Dan Pembelajaran IPA, 4(2), 158-166. https://doi.org/10.30870/jppi.v4i2.3925.

Hendikawati, P., Zahid, M. Z., \& Arifudin, R. (2019). Android-Based Computer Assisted Instruction Development as a Learning Resource for Supporting Self-Regulated Learning. International Journal of Instruction, 12(3), 389-404. https://doi.org/10.29333/iji.2019.12324a.

Kazanidis, I., \& Valsamidis, S. (2019). Technology and Innovation in Learning, Teaching and Education (Vol. 993). https://doi.org/10.1007/978-3-030-20954-4. 
Khamparia, A., \& Pandey, B. (2019). Association of Learning Styles with Different eLearning.pdf.

Lai, C. L., Hwang, G. J., \& Tu, Y. H. (2018). The Effects of Computer-Supported SelfRegulation in Science Inquiry on Learning Outcomes, Learning Processes, and SelfEfficacy. Educational Technology Research and Development, 66(4), 863-892. https://doi.org/10.1007/s11423-018-9585-y.

Liliarti, N., \& Kuswanto, H. (2018). Improving the Competence of Diagrammatic and Argumentative Representation in Physics Through Android-aBsed Mobile Learning Application. International Journal of Instruction, 11(3), 106-122. https://doi.org/10.12973/iji.2018.1138a.

Martin, F., \& Betrus, A. K. K. (2019). Digital Media for Learning: Theories, Processes, and Solutions. In Digital Media for Learning: Theories, Processes, and Solutions. https://doi.org/10.1007/978-3-030-33120-7.

Muchson, M., Munzil, M., Winarni, B. E., \& Agusningtyas, D. (2018). Pengembangan Virtual Lab Berbasis Android Pada Materi Asam Basa Untuk Siswa Sma. J-PEK (Jurnal Pembelajaran Kimia), 4(1), 51-64. https://doi.org/10.17977/um026v4i12019p051.

Nanda, O. A., \& Wilujeng, I. (2018). The Effectiveness of Android-assisted Optical Devices Learning to Improve $S$ tudents ' Conceptual Understanding. Jurnal Penelitian Dan Pembelajaran IPA, 4(2), 105-115. https://doi.org/10.30870/jppi.v4i2.4038.

Özdener, N. (2018). Gamification for Enhancing Web 2.0 Based Educational Activities: The case of Pre-Service Grade School Teachers using Educational Wiki Pages. Telematics and Informatics, 35(3), 564-578. https://doi.org/10.1016/j.tele.2017.04.003.

Pardo, A., Han, F., \& Ellis, R. A. (2017). Combining University Student Self-Regulated Learning Indicators and Engagement with Online Learning Events to Predict Academic Performance. IEEE Transactions on Learning Technologies, 10(1), 82-92. https://doi.org/10.1109/TLT.2016.2639508.

Paristiowati, M., Hadinugrahaningsih, T., Purwanto, A., \& Karyadi, P. A. (2019). Analysis of Students' Scientific Literacy in Contextual-Flipped Classroom Learning on Acid-Base Topic. Journal of Physics: Conference Series, 1156(1). https://doi.org/10.1088/17426596/1156/1/012026.

Pratama, R. A., Ibrahim, N., \& Sarkadi, S. (2019). The Effect of Everyone is a Teacher Here Model and Self-Regulated Learning Towards Learning Outcomes of Indonesian History. JPI (Jurnal Pendidikan Indonesia), 8(2), 208. https://doi.org/10.23887/jpiundiksha.v8i2.17577.

Putri, W. N., \& Billah, A. (2019). Pengembangan Media Pembelajaran Bahasa Arab berwawasan Sains berbasis Mobile Android. LISANIA: Journal of Arabic Education and Literature, 3(2), 163-179. https://doi.org/10.18326/lisania.v3i2.163-179.

Quade, B. N., Parker, M. D., \& Occhipinti, R. (2021). The Therapeutic Importance of AcidBase Balance. In Biochemical Pharmacology (Vol. 183). https://doi.org/10.1016/j.bcp.2020.114278.

Rafika, A. S., Yunan Putri, H., \& Widiarti, F. D. (2017). Analisis Mesin Pencarian Google Scholar Sebagai Sumber Baru Untuk Kutipan. Cerita, 3(2), 13. Retrieved from https://core.ac.uk/download/pdf/285996222.pdf.

Rasmawan, R. (2020). Development of SETS-Based Teaching Materials in Acid-Base Accompanied by Critical Thinking Exercises and Moral Forming. EduChemia (Jurnal Kimia Dan Pendidikan), 5(2), 134. https://doi.org/10.30870/educhemia.v5i2.7934.

Rodiah, S., Komala, R., Rusdi, R., Sciences, N., Jakarta, U. N., \& Timur, J. (2020). The Correlation Between Biology Learning Outcomes and Senior High School Students' Self Concept. Jurnal Penelitian Dan Pembelajaran IPA, 6(1), 141-151. https://doi.org/10.30870/jppi.v6i1.4594.

Schunk, D. H. (2011). Handbook of Self-Regulation of Learning and Performance. In Handbook of Self-Regulation of Learning and Performance. https://doi.org/10.4324/9780203839010.

Setiadi, T., \& Zainul, R. (2019). Pengembangan E-Modul Asam Basa Berbasis Discovery 
Learning Untuk Kelas XI SMA/MA. EduKimia, 1(1), 21-27. https://doi.org/10.31227/osf.io/ugcrk.

Siahaan, P., Setiawan, Y. C., Fratiwi, N. J., Samsudin, A., \& Suhendi, E. (2020). The Development of Critical Thinking Skills and Collaborative Skill Profiles Aided by Multimedia-Based Integrated Instruction on Light Refraction Material. Universal Journal of Educational Research, 8(6), 2599-2613. https://doi.org/10.13189/ujer.2020.080643.

Skinner, J., Byun, R., Blinkhorn, A., \& Johnson, G. (2015). Sugary Drink Consumption and Dental Caries in New South Wales Teenagers. Australian Dental Journal, 60(2), 169175. https://doi.org/10.1111/adj.12310.

Smolakova, M., \& Estokova, A. (2020). Evaluation of Concrete Deterioration Under Simulated Acid Rain Environment. Selected Scientific Papers - Journal of Civil Engineering, 14(1), 47-54. https://doi.org/10.1515/sspjce-2019-0005.

So, W. W. M., Chen, Y., \& Wan, Z. H. (2019). Multimedia e-Learning and Self-Regulated Science Learning: a Study of Primary School Learners' Experiences and Perceptions. Journal of Science Education and Technology, 28(5), 508-522. https://doi.org/10.1007/s10956-019-09782-y.

Starkey, L., Shonfeld, M., Prestridge, S., \& Cervera, M. G. (2021). Special Issue: Covid-19 and the Role of Technology and Pedagogy on School Education During a Pandemic. Technology, Pedagogy and Education, 00(00), 1-5. https://doi.org/10.1080/1475939X.2021.1866838.

Sulistiyarini, D., \& Sabirin, F. (2020). 21st Century Literacy Skill of Information Technology and Computer Education Students. Jurnal Pendidikan Indonesia, 9(4), 576-585. https://doi.org/10.23887/jpi-undiksha.v9i4.24432.

Sya'ban, A. (2005). Teknik Analisis Data Penelitian. Universitas Muhammadiyah Prof Dr Hamka.

Wihartanti, L. V., \& Wibawa, R. P. (2017). Development of e-Learning Microsoft Sway as Innovation of Local Culture-Based Learning Media. Dinamika Pendidikan, 12(1), 5360. https://doi.org/10.15294/dp.v12i1.10582.

Yates, A., Starkey, L., Egerton, B., \& Flueggen, F. (2020). High School Students' Experience of Online Learning during Covid-19: the Influence of Technology and Pedagogy. Technology, Pedagogy and Education, 00(00), 1-15. https://doi.org/10.1080/1475939X.2020.1854337.

Yessi, M., Sudyana, I. N., \& Fatah, A. H. (2019). Pembelajaran Asam Basa Menggunakan LKS Berbasis Learning Cycle 7E untuk Meningkatkan Penguasaan Konsep dan Keterampilan Berpikir Kritis Siswa Sma. Quantum: Jurnal Inovasi Pendidikan Sains, 10(1), 27. https://doi.org/10.20527/quantum.v10i1.5687.

Zhang, C., Yi, X., Gao, X., Wang, M., Shao, C., Lv, Z., ... Shen, C. (2020). Physiological and Biochemical Responses of Tea Seedlings (Camellia sinensis) to Simulated Acid Rain Conditions. Ecotoxicology and Environmental Safety, 192(February), 110315. https://doi.org/10.1016/j.ecoenv.2020.110315. 